\title{
A Review of Solar-Powered Boat Development
}

\author{
Adi Kurniawan ${ }^{1}$
}

\begin{abstract}
Research in the application of renewable energy has intensified in recent years. The possibility of petroleum extinction in the future is forcing researchers to enhance the utilization of renewable energy resources as a substitute for fossil fuel-based technologies in all fields. Ships as one of the most important transportation in the world also require diesel oil as fuel for main propulsion systems and for diesel generators which supply electrical needs. Solar energy has been considered as the most suitable renewable energy resources to substitute the role of fuel in the ships. In this paper, the latest research on the utilization of solar energy in the ship are presented and analyzed to provide information for the researchers who developed the technology of solar-powered boat. The best possible method to utilize the solar energy in the ship is by using catamaran boat with the flat top structure to provide room for placing solar panel. Furthermore, the solar energy extracted from the panel can be optimized by using quadratic Maximization Maximum Power Point Tracking (MPPT) that executed by KY converter, and converted to AC voltage using a multilevel inverter. The use of quadratic MPPT with KY converter is expected to generate a high output power with small DC voltage ripple from the solar panel while the use of a multilevel inverter is expected to convert the DC voltage into high-efficiency AC voltage before supplied to the electric motor propulsion system.
\end{abstract}

Keywords — Solar energy, electric propulsion, maximum power point tracking, hybrid power, battery management system, battery charger.

Abstrak - Penelitian di bidang aplikasi energi terbarukan semakin diintensifkan dalam beberapa tahun terakhir. Kemungkinan mengenai habisnya cadangan minyak bumi di masa mendatang memaksa para peneliti untuk meningkatkan penggunaan sumber energi terbarukan sebagai pengganti dari teknologi berbasis bahan bakar fosil di semua bidang. Kapal laut sebagai salah satu transportasi paling penting di dunia juga membutuhkan minyak diesel sebagai bahan bakar pada sistem propulsi utama, serta untuk bahan bakar pada generator diesel sebagai penghasil energi listrik. Energi matahari dipertimbangkan sebagai sumber energi terbarukan yang paling tepat untuk menggantikan peran bahan bakar di kapal. Pada makalah ini ditampilkan analisis tentang riset-riset terbaru mengenai pemanfaatan energi matahari di kapal untuk memberikan informasi pada peneliti-peneliti yang mengembangkan teknologi kapal bertenaga matahari. Teknologi terbaik yang dapat digunakan untuk penggunaan energi matahari pada kapal adalah dengan menggunakan kapal katamaran yang mempunyai struktur atap datar sehingga tersedia ruang yang cukup besar untuk meletakkan panel surya. Selain itu, energi matahari yang dihasilkan oleh panel surya dapat dioptimalkan dengan menggunakan metode quadratic maximum power point tracking yang dieksekusi oleh konverter KY, kemudian dikonversi menjadi tegangan AC menggunakan multilevel inverter. Penggunaan quadratic MPPT pada konverter KY diharapkan dapat menghasilkan daya keluaran yang tinggi dengan riak tegangan yang rendah, sedangkan penggunaan multilevel inverter diharapkan dapat mengkonversi tegangan DC menjadi tegangan AC secara efisien sebelum diberikan pada sistem propulsi motor listrik.

Kata Kunci-Energi matahari, propulsi electrik, maximum power point tracking, tenaga hibrid, sistem manajemen baterai, pengisi battery.

\section{INTRODUCTION}

$\mathrm{O}$ bviously, people have a great dependence on fossil fuels. Almost all vehicles that ease human mobility are powered by fossil fuels. In another field, electricity producer is dominated by fossil-fueled generators, either oil or coal. Ironically, scientist classifies that fossil fuel is non-renewable energy resources. This means that someday in the future, there is no more oil or coal in this world and people can't use a vehicle or electric equipment anymore if there are no replacement for fossil-fueled technology [1], [2]. .

Researchers in various fields are studying about renewable energy, including the marine engineer. One of marine engineer job is designing ship propulsion system and ship electrical installation. Conventional ship propulsion system is using diesel engine while the common conventional electrical producer in the ship is also diesel generator. Those two instruments need a fair amount of diesel fuel. Therefore, marine engineer held the responsibility to develop renewable energy-based technology for ship electrical source and main propulsion system in order to preserve ship operation when fuel is no more available in the future. The use of renewable energybased technology may also reduce the ship operation cost because of the uncertain price of oil [2]-[5].

Research of renewable energy in the ship is very important because the ship is a very important transportation. Not only important for human transport, the ship is also a very effective vehicle for logistics delivery. Indonesia as a country which has a vast area of water, consisting of sea, coast, river and lake, requires a great number of the ship that can operate efficiently.

One of the renewable energy resources that intensively developed in ship application is solar energy. A solar panel or photovoltaic (PV) is a solar energy converter which operates quietly, and unlike wind turbine, it has no rotating parts that may affect ship stability. This is perfect condition for Indonesia because Indonesia has a high potential of solar energies.

There are many aspects being investigated and developed in a solar-powered boat application. PV lowefficiency issue lead research about Maximum Power Point Tracking (MPPT) method for PV application in the ship [7]-[9]. The limited available area in ship also bring out an investigation of PV placement in the existing ship

${ }^{1}$ Adi Kurniawan is with Departement of Marine Engineering, Faculty of Marine Engineering, Institut Teknologi Sepuluh Nopember, Surabaya, 60111, Indonesia. E-mail: adi.kurniawan@ne.its.ac.id 
or create new ship design which can accommodate PV array [2], [10]-[12]. The discontinuity of solar energy availability, for example at night or at rainy condition necessitates battery as a part of PV system in the ship. There are some researches which focused in battery management system of electric vehicle application, such as in [13], [14]. Data management system and online visualization also need an attention to developing solar boat system. The online real-time data are very helpful information that may be used to analyze the performance of the ship. The data management system and online visualization for solar boat system have been developed in [15]. The other important issue on the solar-powered boat is the electric propulsion. The diesel motor in the conventional ship is replaced by an electric motor in a solar-powered boat application. To enhance electric propulsion performances, some researches have been done. This new propulsion technology is presented in [16]-[18].

This paper explained the application of solar-powered boat that has been developed, including the evolution of technology in each component and analysis of the advantages and disadvantages of those components. Hopefully, this paper can be a helpful reference and guide for every researcher that interested to study and develop advanced solar-powered boat application.

\section{OVERVIEW OF SOLAR-POWERED BOAT ELECTRICAL SYSTEM}

Basically, there are two types of solar-powered boat. The first one is the combination of solar power with existing diesel generator while the second is the utilization of solar power as the only electrical supply to handle all electrical loads [3], [18], [19].

PV-diesel hybrid system is the combination of solar power with diesel generator which usually used in a big ship that has high total electrical loads. In this kind of ship, PV alone may be unable to fulfill all power demand due to the space limitation.

The basic concept of PV-diesel hybrid system is reducing the power generated by diesel generator in conventional diesel ship. The advantages of reducing power generated by diesel generator are the decrease of fuel, and consequently, reducing operation cost and exhausted gas.

An example of PV-diesel hybrid system in a ship has been developed in [20]. The test subject in that research is "Auriga Leader", one of car carrier ship in Japan. The 60,213 gross ton ship has been a test subject since finished built in 2008. One of the problems that not yet perfectly overcome in that research is how to stabilize the output power of the hybrid system due to the fluctuation of weather condition on the sea. PV is very sensitive towards the change of sun irradiation and ambient temperature. A slight change of sun irradiation or ambient temperature may affect power produced by PV significantly.

Some researches to stabilize PV-diesel hybrid system output power on the land such as [21]-[25] may be adopted for ship application. Al-Alawi et.all [20], Suryoatmojo et.all [21] propose the utilization of Artificial Neural Network (ANN) to control the output power. The use of sliding mode controller to overcome this problem is presented in [22], [23], while Datta et.all [24] propose fuzzy logic controller. All of the researches above are considered successfully suppress the fluctuation of hybrid system output power. Therefore, one of those methods should be considered to be applied in PV-diesel hybrid system on the vessel.

Another example of PV-diesel hybrid system in the ship has realized in [3], [19]. The so-called "green ship" is operated between Geoje Island and Somaemuldo Island, South Korea. This ship is an 80 gross ton cruise ship. The aim of the green ship project is not only to reduce fuel consumption but also to support electrical grid on Geoje Island. The power ratings of the hybrid PV-diesel is 3.2 $\mathrm{kW}$. The problems that not perfectly resolved yet in this project are the ship stability and high current harmonics when supplying electrical grid in Geoje Island. The ship stability issue may be resolved by adopting better ship design. The current harmonics issue may be resolved by designing proper filter.

The common topology of PV-diesel hybrid system in the ship is shown in Figure 1. The system is consist of PV array, DC-DC converter as a power conditioner, maximum power point tracking, battery and its management controller, a three-phase inverter to convert DC voltage into three-phase AC voltage, diesel generators, and Main Switch Board (MSB) as a merging spot of those two power. The power generated by the hybrid system supply main electric propulsion and the other loads such as lighting and general use, thruster, an auxiliary machine, etc.

The second type of solar-powered boat is PV as a sole electrical supplier. The system that uses solar power only, usually designed for small craft boats, such as recreational boat and small fishing boat. This kind of boat usually doesn't use much electrical equipment and only need relatively small electric motor as main propulsion. Therefore, PV alone is sufficient to fulfill the electrical load.

The only different between the topology of PV-diesel hybrid system and PV only system is the presence of diesel generator. The other equipment is exactly the same, but likely with smaller ratings. This system also needs power conditioner, maximum power point tracking, battery as a stabilizer and back-up power, and inverter. The topology of PV only system in solar boat application is shown in Figure 2.

An example of existing only solar-powered boat is presented in [26]. The solar boat is developed by Framby Udde Resort cooperated with Dalarna University and Scandinavian Heartland. The boat is functioned as an environment friendly recreational boat for tourist. The only load in that boat is an $800 \mathrm{~W}$ rated electric motor. The number of PV installed in the boat is four, with each PV rated power is $250 \mathrm{~W}$. However, the capacity of the boat is only for two people, and since there is no lighting on the boat, is it unlikely to operate the boat at night. It will be an excellent development if the boat can accommodate more people and can sail at night.

\section{DEVELOPMENT OF SOLAR-POWERED BOAT COMPONENTS}

As described above, a solar-powered boat system consists of PV array, PV power conditioner, MPPT, battery and its management system, inverter, and electrical motor as the main load. This section will discuss the development of each component in solar-powered 
boat application, and also the development of boat construction and PV placement design.

\section{A. Development of Solar Boat Design}

Construction and PV placement design is an important issue in order to realize a solar-powered boat. The main problem is the limited space to mount PV modules in the ship. The place to mount the PV modules must be exposed to sunlight in order to get higher power from PV. The higher the intensity of light received by PV module, the higher the power generated by PV module. The addition of PV system on the ship may also arise stability problem because the total weight of PV modules, battery, and another equipment increases the burden of the ship.

Rivera-solorio et.all [11] designed a small solarpowered boat for tourism considered rational design, safety, and reliability approach. The author and his team propose a catamaran boat with flat top structure, maximum speed $15 \mathrm{~km} / \mathrm{h}$, and Length over All (LOA) 14 $\mathrm{m}$ as a test project. The propulsion of the ship is two electric motors with $8 \mathrm{~kW}$ rated power. The type of the electric motor is the permanent magnet synchronous motor.

The flat top structure is proposed in that project as a place to mount PV array. If the PV module is mounted on top side of the deck, the PV will receive sunlight without obstructed. The area that available for PV array is $55 \mathrm{~m} 2$. This project uses $42 \mathrm{PV}$ panel with the total power at rated weather condition is $9.45 \mathrm{~kW}$. The remaining problem of the project is the number of battery that reaches 52 . With the weight of each battery is $19.6 \mathrm{~kg}$, the total weight for battery only is $1020 \mathrm{~kg}$.

Stuart et.all [12] focuses on design and structure of the boat in a solar-powered boat application. The research uses computational aid tools such as CFD (Computational Fluid Dynamics), CAM (Computer Aided Manufacturing), FEM (Finite Element Method) and CAD (Computer Aided Design) software. The hull design is created using CAD and CAM, then the stress and deformation analysis are performed with FEM program. The hydrodynamics analysis of the designed structure has also been performed by using CFD simulation. The validation of the design results is performed in scale boat prototype. Designing the boat using software aid may increase the creativity of the design than drawing the geometry. Unfortunately, dimensional similarity can't be achieved in this project due to the large difference in size between the scales and full-size prototype.

Mahmud et.all [2] designed simple but reliable solarpowered boat for short distance transportation, about 25 $\mathrm{km} /$ day. The purpose of the designed boat is for inland navigation of developing countries. In this project, the PV modules are placed on the roof with $7 \mathrm{~m} 2$ available area. The material used for the ship is light composite material. Though expensive, the use of this material can reduce the total weight and increase the passenger's capacity. The other design is created by the objective function to minimize the cost. As a result, the solar-powered boat developed in this research is relatively inexpensive but reliable and efficient. It can be concluded that this solarpowered boat is very suitable to use in developing countries. However, the design of the ship is limited for particular weight carrier and particular distance. If the number of passenger or distance aimed is changed, the number of PV module, battery, and motor specification must be recalculated.

\section{B. PV Module in Solar Boat Application}

The photovoltaic or solar cell is a device which can convert solar energy into electric energy. PV is intensively developed because it is a clean energy. The major issue of PV module until recently is its efficiency. Many types of research had been discussed improvement of PV efficiency and looks like this discussion will continue in a long time.

There is no research that specially discuss developing PV for marine application. However, Glasner and Appelbaum [27] present a test of PV module efficiency in naval condition. The PV panel is installed on a ship, then, the data is gathered during the voyage. The result is that there is a 1-volt voltage difference between in voyage test and in the stationary test, due to the ship motion. Therefore, we can conclude that if a researcher wants to develop solar-powered boat, he have to consider that the output of the PV may a bit different than the rating because the rating is based on the stationary test.

The more understanding of PV behavior in sailing condition may be achieved if the more data such as temperature, humidity, sun irradiation, and ship course can be obtained.

\section{DC-DC Converter as Power Conditioner}

In a PV system application, a power conditioner is essential equipment that can enhance system efficiency. Power conditioner may regulate PV system output voltage or help generate PV maximum output power if there is MPPT applied. The common power conditioner used in PV system application is DC-DC converter. If the PV system supplies AC load, the output of DC-DC converter is converted into AC voltage by single-phase or threephase inverter, depending on the load supplied. Recently, there are several studies about single-stage inverter as the power conditioner, by combining the utility of DC-DC converter and conventional inverter. However, it is still difficult to apply MPPT into the single-stage inverter. Therefore, DC-DC converter is still regularly used in PV system.

Basically, there are 3 types of DC-DC converter. The first is boost type converter, which the output voltage is greater than the input voltage. The second is buck type converter, which the output voltage is less than the input voltage. The last one is buck-boost type converter, which the output voltage can either greater, or less than the input voltage. The conventional boost, buck, and the buck-boost converter are shown in Figure 3. Buck type converter is usually only used in PV standalone system with a low voltage DC load. Boost type converter is often used either in PV grid-connected system or standalone system with a relatively high voltage load. Buck-boost type converter is used in a system that needs flexibility of load supplied. A study comparing the efficiency between boost type and buck type converter topology in PV MPPT application is presented in [28], which the result denote that the use of boost type converter has higher efficiency.

There is no research that studying of DC-DC converter for special marine use, because basically, there is no correlation of weather condition or ship motion with the DC-DC converter performance. However, the study of DC-DC converter performance improvement on PV 
system is continuously done. There are several new DCDC converter topologies developed specifically for PV system application. Kumar et.all [29] use Cuk converter on PV grid-connected system. Cuk converter is a buckboost type converter. The main advantage of Cuk converter comparing with the conventional buck-boost is the output voltage is not reversal. In that research, the performance of the system with Cuk converter is compared with the system using boost converter. The results show that the system with Cuk converter has higher efficiency and smaller ripple voltage.

Hwu and Yau [30] propose dual output converter for PV system. The first output can step up the input voltage multiple times while the second output can either step up or step down the input voltage in limited range. The performance of the converter has been validated through computer simulation. However, the real implementation has not made yet and need validation before used in a solar-powered boat application.

The other evolved DC-DC converter technology that may be nominated to use in solar boat system is $\mathrm{KY}$ converter that presented in [31]. Actually, this new boost type converter is not built specifically for PV application system. However, this converter has small voltage ripple and fast transient response. A converter with small ripple is beneficial to reduce the probability of the system being malfunctioned. The fast transient response of this converter is very suitable for marine use because the rapid changes of weather in the naval environment [32]. This converter has been applied for standalone PV system in [33] and shows good performance. The only drawback of this converter is the limited range to increase the output voltage. Figure 4 shows the topology of Cuk converter, $\mathrm{KY}$ converter, and dual output converter.

\section{Development of PV Maximum Power Point Tracking in Solar Boat Application}

Maximum power point tracking is a method to increase PV systems efficiency by maximizes PV output power at every weather condition. PV module has different maximum power at each weather condition, especially at different solar irradiation. The value of PV maximum power at each weather condition can be obtained if the PV output voltage is at certain value, called Maximum Power Point (MPP) voltage. MPPT has a role to generate optimum voltage reference for DC-DC converter so that $\mathrm{PV}$ can produce its maximum power at every different condition.

There are dozens of PV MPPT method has been developed. Some of them are non-artificial intelligent techniques while some are artificial intelligent based. The examples of non-artificial intelligent MPPT methods are Perturb \& Observe, incremental conductance, and fractional open circuit method. The most well-known artificial intelligent MPPT methods are fuzzy logic [9] and neural network. References Ko et.all [7], Haryanto et.all [8] specifically develop MPPT for solar-powered boat application. MPPT in moving object such as boat must have fast response because the sun irradiation may changes rapidly. Both of those references use modification of Quadratic Maximization algorithm to track PV maximum power. Quadratic Maximization algorithm works by approximate correlation between PV solar-powered boat application. power and converter duty cycle through quadratic curve function. The limitations of Quadratic Maximization algorithm for moving object are duty shafting, re-tracking and convergence. This algorithm is validated through comparing simulation results with $\mathrm{P} \& \mathrm{O}$ algorithm under change of either sun irradiation or temperature condition. The results show that the proposed algorithm has fast response and better efficiency than $\mathrm{P} \& \mathrm{O}$. The proposed method also been applied in model ship and show good results. It can be concluded that the proposed MPPT method is very suitable for solar-powered boat system.

\section{E. Development of Battery Management System in Solar Boat Application}

Battery is an important part in PV system, because PV can't operate continuously, especially at night and at cloudy weather. With the presence of the battery, the continuity of the supply to the load will be maintained. The battery becomes more important in the solar-powered boat application. It will be very dangerous if the electric propulsion stop working in the middle of the sail because the PV is not getting sufficient light and there is no backup power. In order to make the battery works efficiently and extends battery lifetime, a proper battery management system is needed. Xing et.all [13], R. Leiner [14] proposed battery management system for electric vehicles such as solar boat.

Xing et.all [13] proposed a modular battery management system for hybrid electric vehicle. There are three important issues that specially improved from this study. Those issues are accumulated charge measurement, voltage measurement, and equalization. The system consists of local Electronic Control Unit (ECU) provided one for each battery, and one central ECU. The local ECU has function to measure voltage and temperature of each battery, while central ECU measure current, synchronizes voltage, determines State of Charge (SoC) and some other task. The validation of the proposed system is done through the test of the prototype under temperature between $-20^{\circ} \mathrm{C}$ and $50^{\circ} \mathrm{C}$. The prototype is tested to manage 12 cells and 48 cells Li-Ion battery. Both of the current \& charge measurement test and equalization test show adequate result. However, if unbalance voltage occur, the proposed method needs long time to re-balance the voltage, especially when the current is low.

R. Leiner [14] designed a battery management system consisting of both hardware and software. The software is controlling the behavior of the hardware which consists of safety circuit, sensor, data acquisition, charge control, and thermal management. The software works based on the parameters measured by sensor, which are battery SoC, state of health $(\mathrm{SoH})$, cell balancing, and fault detection. In the contrary with common charging method, the proposed method is not using constant charging current. The charging current may be varies, with the objective function is the balance of the battery cell. The proposed method shows good performance under laboratory test. However, this proposed method had not tested under vibration or extreme weather that may occur during sail. If this method can successfully manage charging and discharging process of the battery under sail condition, it will be a great development for 


\section{F. Development of Electric Propulsion}

In most of solar-powered boat, electric motor acts as main propulsion. Electric motor needs electric energy that is supplied by PV. Basically, there are two types of electric motor, which are DC motor and AC motor. AC motor is also divided into two type, synchronous motor and induction motor. Before the development of power electronics, DC motor is preferred because it is easier to control the speed. As a development of power electronics become more advance, controlling the speed of $\mathrm{AC}$ motor become easier. Although the cost of the AC motor controller is more expensive than DC motor controller, $\mathrm{AC}$ motor is preferred to use because the motor itself is cheaper, has less weight and smaller dimensional size at the same power compared than DC motor [34].

Some researches such as in [16]-[18] has been done to investigate and improve the performance of electric motor propulsion in solar boat application.

Sousa et.all [16] presented a monitoring of electric propulsion supplied by $4 \mathrm{kWp} \mathrm{PV}$. The project boat is built in Netherland. The electric propulsion is use $48 \mathrm{~V}$ while the other load such as navigation and communication use $12 \mathrm{~V}$. The monitoring shows that no power shortages occur, but many aspects not been validated yet.

Soeiro et.all [17] proposes a fuzzy logic based indirect vector controller to optimize the efficiency of solar boat drive. This controller regulates the flux level to reach optimum balance between the core and chopper losses. The system is use dc link capacitor between the output of boost converter and the input of PWM inverter. The experiment uses 5 HP induction motor which tested in laboratory. The proposed system shows great efficiency performance by reducing losses in lower machine and in inverter, reducing cooling requirements, and reducing voltage stress in the switch which turn into reliability enhancement.

Lee et.all [18] proposes a sophisticated system of solarpowered boat. The PV arrays are divided into two groups, where each group is connected to a dc-dc converter. The PV output power is stored into battery bank then converted into AC power by multilevel inverter to supply two Permanent Magnet Synchronous Motors (PMSM). The utilization of multilevel inverter resulting very low line current ripples because there are several terminal level voltages at the PMSM. Another unique concept proposed in this study is the converter is arranged using Gallium Nitride (GaN) power FET Semiconductors. Besides, the switching frequency reaches $1 \mathrm{MHz}$, reducing the volume of the passive component in the converter. The experimental results show great efficiency and ready to produce in industrial scale. Figure 5 presents the concept of the proposed system.

\section{G. Data Management System}

Data management system and online visualization is another important aspect in developing solar-powered boat. Applying data management that can be observed online makes it easier to analyze or monitoring the performance of the developed solar boat. A study about data management system and online visualization of the solar boat is presented in [15].

The proposed system aims to get data for onboard staff, data online for off-board staff, storage data for a long period, and online graphical analysis of stored data. All of the data can be used to make a longtime useful analysis such as equipment performances under sail condition.

The data are obtained by putting the sensor in the desired equipment. The data measured are PV output voltage and current, battery voltage and current, converter current, converter temperature, motor temperature, motor speed, motor current, speed above water, water temperature, and air temperature. All of the measured data are sent to the microcontroller of the black box and stored in memory. Then, the black box will transmit the data through GPS transmitter to the onboard autopilot system and to the base station in HTWG-Konstanz, University of Applied Sciences. The autopilot system is responsible for calculating the speed and determining the course of the boat based on the data received from the black box. The real-time data can be observed through onboard computer and computer in the base station. The base station also held the responsibility to store the data and makes online visualization of the data.

One example of the benefit of the proposed system is the detection of the degrading battery cell. By detecting the degrading cell, the schedule of battery replacement can be prepared before the battery becomes defective. The diagram of Information Management System is presented in Figure 6.

\section{RESULT AND ANALYSIS}

Based on the previous section, the sophisticated components of the solar boat have been developed. If all the best technology on each component can be integrated, a high-efficiency solar-powered boat can be built.

There are two possibilities to develop an advanced solarpowered boat. The first is hybrid solar-diesel energy for a big vessel while the second is all solar-powered boat for a small vessel.

The results from several Lee et.all [3], Nippon Yusen Kaisha [19], which are discussed hybrid solar-diesel boat, indicate that this type of boat can reduce the fuel consumption and emission of $\mathrm{CO} 2$. When the percentage of $\mathrm{PV}$ is up to $70 \%$, the fuel saving is reaching 1.6-kilo liter, while the $\mathrm{CO} 2$ production is decreasing to 2.1 tons in a year [19]. According to its fuel saving, the payback period of this type of boat can be achieved after 12 years. However, there are two problems regarding hybrid PVsolar energy. First, the technology of hybrid solar-diesel energy is more complex because the voltage produced by PV has to be regulated to be in the same magnitude, frequency and in phase with the voltage generated by a diesel generator. The second problem is the necessity to provide source-load management system due to the uncertainty of PV output power.

The all-solar powered boat is simpler than hybrid system because the voltage produced by the PV only needs to be adjusted with the load requirement. This type of boat is very suitable to be implemented on small vessels such as fishing boat and recreational boat. This will results zero emission in fishing and tourism area. In this time, it is still difficult to develop all-solar boat in big vessels because the limitation space on the ship and relatively low efficiency of PV panel itself.

The all solar-powered boat consist of MPPT to extract the maximum power from the PV, DC-DC converter as a power conditioner, battery, battery management system, 
inverter, and AC induction motor as motor propulsion. The other factor which affected the performance of the boat is the shape and structure of the boat itself. Besides the advantage in the technical area, this type of system also has a cheaper operational method and lower emission than the hybrid system due to no consumption of fuel oil. The research in [11] stated that an existed $14 \mathrm{~m}$ long recreational boat which converted to all solar-powered boat can be built without changing the dimension of the ship. The solar boat needs additional investment cost of $50,000 \$$, but the annual saving is estimated to $5,000 \$$, resulting only 10 years to reach the break-even point. The exhaust gases which can be reduced by using this boat is $\mathrm{CO} 2$, NOx, and Sox which is dangerous for the ecosystem. The concept design proposed in the same reference is a possible structure for build a solar-powered boat. The use of catamaran boat with a flat top roof as a place to mount PV is the best possible choice because there is a big space for PV panel, and the PV may get the highest solar irradiation because it will receive sunlight without obstructed by ship building.

In order to extract PV maximum power in all conditions, maximum power point tracker is needed. Quadratic MPPT algorithm proposed in [8] is designed for the solarpowered boat. A fast response MPPT is needed in the solar-powered boat due to the rapid changes of position of the boat against the sun, resulting changes in sun irradiation received by the PV. The proposed MPPT show good results both in simulation and experiment. When the sun irradiation is changed to $400 \mathrm{~W} / \mathrm{m} 2$ to $900 \mathrm{~W} / \mathrm{m} 2$, the only small amplitude of perturbation is found and the maximum power point can be found after only $200 \mathrm{~ms}$. The MPPT algorithm in this reference is executed using conventional DC-DC converter. The results will be greater if it is executed using faster transient response and smaller output voltage converter such as KY converter proposed in [31].

The AC induction motor is chosen as the best possible answer for the main propulsion due to its advantages. A high efficient inverter is needed in order to efficiently convert DC voltage from the PV into AC voltage. A multilevel inverter such as proposed in [18] is worth considering to be applied. The research on that paper is using two levels voltage source inverter with power rating $3 \mathrm{~kW}$. The input DC voltage is $96 \mathrm{~V}$ with $250 \mathrm{kHz}$ frequency. The result shows very low line current ripple injected to the induction motor which can increase the performance and preserve a longer lifetime of the motor.

Combining all of those best technologies in one small solar-powered boat may not easy. There are a lot of synchronization and modification needs to be made in order to develop a very advanced solar-powered boat. However, the idea to combine all of the best components is not impossible and should be considered.

\section{CONCLUSION}

The technology to establish solar-powered boat is developing in advance. Building a ship powered by hybrid $\mathrm{PV}$-diesel generator, or all powered by PV, is not a daydream anymore. However, the research in this field must be continuously done in order to increase the efficiency of the system.

Based on the recent publication of the solar-powered boat technology development, some researchers are considered to be references to build a solar boat. A catamaran boat with top flat structure is the best possible boat to provide adequate spaces to install the solar panel. The best method to optimize the efficiency of solar energy extracted by a solar panel is by using quadratic MPPT method which is proven to be able to generate maximum power in rapid changes of solar irradiation. The MPPT algorithm shall be executed with KY converter which has fast transient response and small voltage ripple. The best candidates for the electric motor as propulsion is AC induction motor. Multilevel inverter shall be used to efficiently convert DC voltage from the solar panel, into $\mathrm{AC}$ voltage required by an induction motor. The combination of those technologies is expected to provide a high efficient solar-powered boat.

\section{REFERENCES}

[1] N. Khaehintung, P. Sirisuk and W. Kurutach, "A Novel ANFIS Controller for Maximum Power Point Tracking," in The Fifth International Conference on Power Electronics and Drive Systems, Singapore, 2003.

[2] K. Mahmud, S. Morsalin and M. I. Khan, "Design and Fabrication of an Automated Solar Boat," International Journal of Advance Science and Technology, vol. 64, p. 31-42, 2014.

[3] K. J. Lee, D. S. Shin, J. P. Lee, D. W. Yoo, H. K. Choi and H. J. Kim, "Hybrid Photovoltaic/Diesel Green Ship Operating in Standalone and Grid-Connected Mode in South Korea Experimental investigation," in IEEE Vehicle Power and Propulsion Conference, Seoul, 2012.

[4] S. Babu and J. V. Jain, "On-Board Solar Power for Small-Scale Distant-water Fishing Vessels," in Global Humanitarian Technology Conference, San Jose, CA, 2013.

[5] E. S. Koenhardono, E. B. Djatmiko, A. Soeprijanto and M. I. Irawan, "Neural Network-Based Engine Propeller Matching ( NNEPM ) for Trimaran Patrol Ship," Applied Mechanics and Materials, vol. 493, p. 388-394, 2014.

[6] S. H. Ko and R. M. Chao, "Photovoltaic dynamic MPPT on A Moving Vehicle," Solar Energy, vol. 86, no. 6, p. 1750-1760, 2012.

[7] S. H. Ko and R. M. Chao, "A Quadratic Maximization MPPT Method Applied to PV System on a Moving Vehicle," in Power and Energy Engineering Conference, Shanghai, 2012.

[8] E. Haryanto, A. A. Masroeri, A. Kurniawan and A. S. Surya, "Optimasi Boost Converter Panel Surya sebagai Sumber Energi Alternatif Penerangan Kmp Allu. dengan Metode Logika Fuzzy," Jurnal Teknik ITS, vol. 4, no. 2, p. B124 - B129, 2015.

[9] S. Freire, "Designing and Building a Solar Powered Model Boat," International Baccalaureate Organization, Geneva, 2009.

[10] G. S. Spagnolo, D. Papalillo, A. Martocchia and G. Makary, "Solar-Electric Boat," Journal of Transportation Technologies, vol. 2, no. 2, p. 144-149, 2012.

[11] C. Rivera-solorio, A. J. Garcia-Cuellar and A. Flores, "Design and Construction of a Boat Powered by Solar Energy with the Aid of Computational Tools," International Journal of Engineering Education, vol. 29, no. 2, p. 380-387, 2013

[12] T. Stuart, F. Fang, X. Wang, C. Ashtiani and A. Pesaran, "A Modular Battery Management System for HEVs," in SAE Int 2002 Future Car Congress, Arlington, Virginia, 2002.

[13] Y. Xing, E. W. M. Ma, K. L. Tsui and M. Pecht, "Battery Management Systems in Electric and Hybrid Vehicles," Energies, vol. 4, no. 11, p. 1840-1857, 2011.

[14] R. Leiner, "Research Solar Power Boat - Data Management and Online Visualization," in AFRICON, Windhoek, 2007.

[15] G. Loois, F. P. H. Wouters, G. M. Koerts and T. C. J. Van Der Weiden, "Monitoring Results of PV for Electric Propulsion in Recreational Boating," in Photovoltaic Energy Conversion, Waikoloa, Hawai, 1994

[16] G. C. D. Sousa, D. S. L. Simonetti, , E. E. C. Norena and J. P. Rey, "Efficiency Optimization of a Solar Boat Induction Motor Drive," in Industry Applications Conference, Rome, 2000.

[17] T. B. Soeiro, T. J. Jappe, W. M. dos Santos, D. C. Martins and M. L. Heldwein, "Propulsion and Battery Charging Systems of an AllElectric Boat Fully Constructed with Interleaved Converters Employing Interphase Transformers and Gallium Nitride ( $\mathrm{GaN}$ ) Power FET Semiconductors," in Applied Power Electronics Conference and Exposition (APEC), Fort Worth, TX, 2014. 
[18] K. Lee, D. Shin, D. Yoo, H. Choi and H. Kim, "Hybrid Photovoltaic/Diesel Green Ship Operating in Standalone and GridConnected mode e Experimental Investigation," Energy, vol. 49, p. 475-483, 2013.

[19] Nippon Yusen Kaisha, "NYK Line," Nippon Yusen Kabushiki Kaisha, K. H. Industries, M. T. Institute, and N. K. Kyokai, "World's First Solar-Power-Assisted Vessel Further Developed Car Carrier Auriga Leader to be Fitted with Hybrid Power Supply System and Ballast-Water Management System,, 25 May 2011. [Online]. Available: http://www.nyk.com/english/release/1414/ne_110525.html.

[20] A. Al-Alawi, S. M. Al-Alawi and S. M. Islam, "Predictive Control of An Integrated PV-diesel Water and Power Supply System using An Artificial Neural Network," Renewable Energy, vol. 32, no. 8, p. 1426-1439, 2007.

[21] H. Suryoatmojo, A. Kurniawan, F. A. Pamuji, I. G. P. S. Wijaya and H. Innah, "A Robust Frequency Control Approach in PVDiesel Hybrid Power System," IPTEK Journal of Proceeding Series, vol. 1, no. 1, p. 188-194, 2014.

[22] H. Suryoatmojo, A. Kurniawan, F. A. Pamuji, Nursalim, Syaffaruddin and H. Innah, "Smart Frequency Control in PVDiesel Hybrid Power System," in Seminar on Intelligent Technology and Its Application, Surabaya, 2014.

[23] Y. Mi, Y. Fu, J. B. Zhao and P. Wang, "The Novel Frequency Control Method for PV-diesel Hybrid System," in International Conference on Control and Automation (ICCA), Hangzhou, 2013.

[24] M. Datta, T. Senjyu, A. Yona, T. Funabashi and C. K. Kim, "A Frequency-Control Approach by Photovoltaic Generator in a PV Diesel Hybrid Power System," IEEE Transactions on Energy Conversion, vol. 26, no. 2, p. 559-571, 2011.

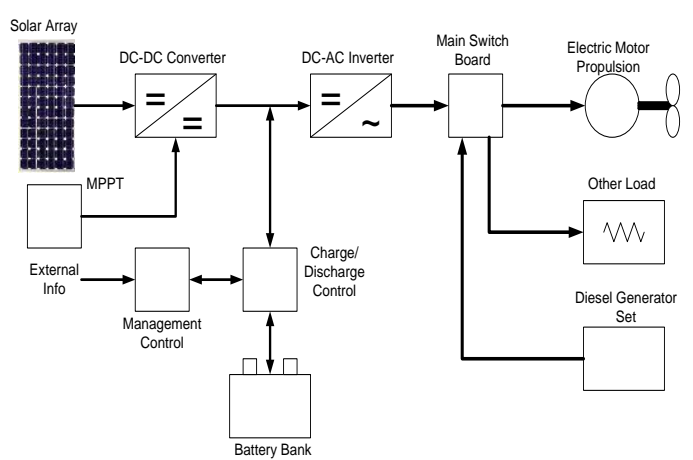

Figure 1. Common topology of PV-diesel hybrid system in ship.
[25] Framby Udde Resort and S. Heartland, The Solar Boat, Scandinavian: Framby Udde Resort and S. Heartland, 2011.

[26] O. Cristea, "Testing of PV Module Efficiency in Naval Conditions," in The 8th International Symposium on Advanced Topics in Electrical Engineering, Bucharest, 2013.

[27] I. Glasner and J. Appelbaum, "Advantage of Boost vs. Buck Topology for Maximum Power Point Tracker in Photovoltaic Systems," in 19th Convention of Electrical and Electronics Engineers, Jerusalem, 1996.

[28] M. S. Syam and T. S. Kailas, "Grid connected PV system using Cuk converter," in International Conference on Microelectronics, Communication and Renewable Energy (ICMiCR), Kanjirapally, 2013.

[29] A. Kumar, V. Gautam and P. Sensarma, "A SEPIC Derived Single Stage Buck-Boost Inverter for Photovoltaic Applications," in International Conference on Industrial Technology, Busan, 2014.

[30] K. I. Hwu and Y. T. Yau, "A KY Boost Converter," IEEE Transactions on Power Electronics, vol. 25, no. 11, p. 2699-2703, 2010.

[31] A. Kurniawan and W. M. Faizal, "Metode pengaturan Tegangan pada Konverter KY menggunakan Kontroler PI," Inovtek, vol. 5 , no. 1, p. 12-20, 2015.

[32] A. Kurniawan, "Maximum Power Point Tracking for Stand Alone Photovoltaic System with KY Converter," International Journal of Low-Carbon Technologies, vol. 1, no. 2, p. 1-6, 2012.

[33] A. Kurniawan and A. Harumwidiah, "Strategi Kendali Kecepatan Motor Induksi Menggunakan PWM Inverter Berbasis Jaringan Saraf Tiruan," TRANSMISI, vol. 17, no. 2, p. 83-88, 2015

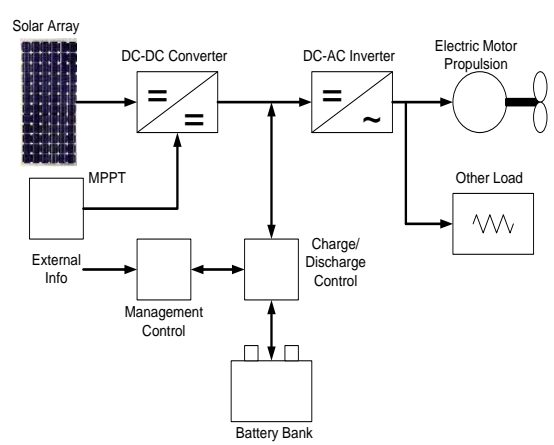

Figure 2. Common topology of PV-only system in ship.

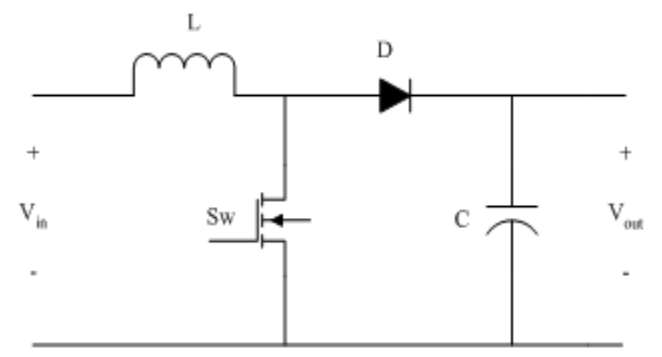

(a)

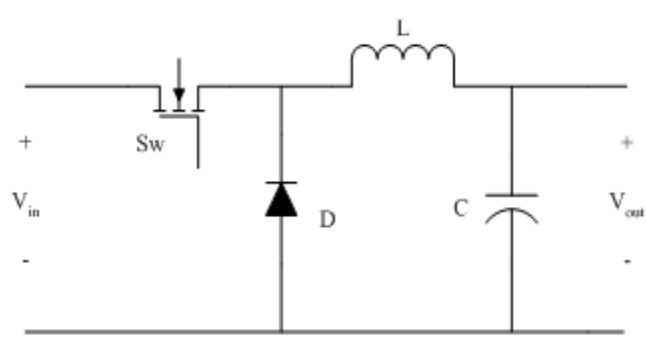

(b)

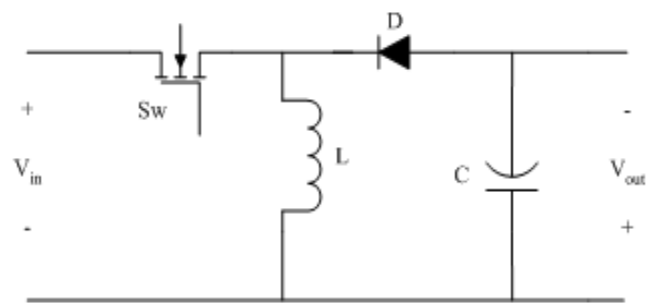

(c)

Figure 3. Topology of (a) Conventional boost converter (b) Conventional buck converter (c) Conventional buck-boost converter. 


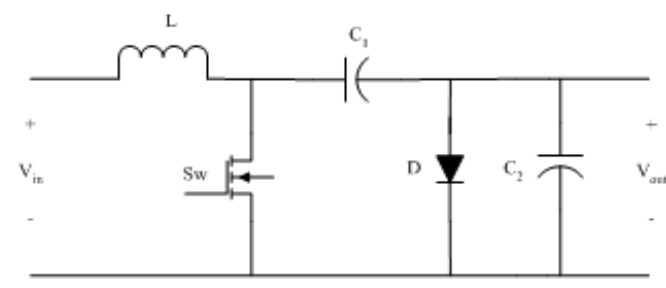

(a)

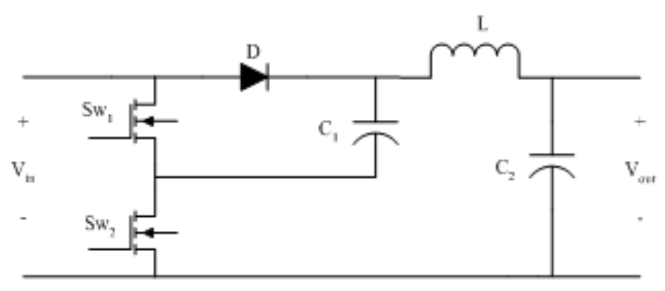

(b)

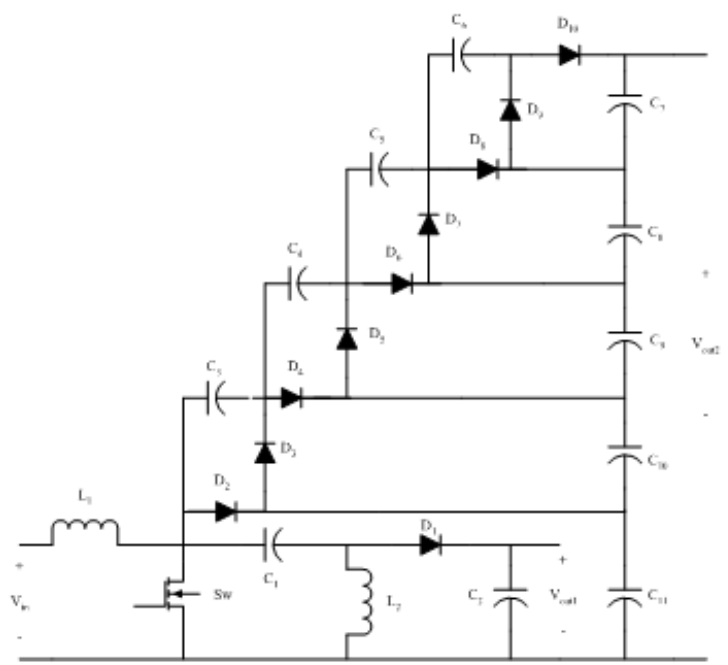

(c)

Figure 4. Topology of (a) Cuk converter (b) KY converter (c) Dual output converter.

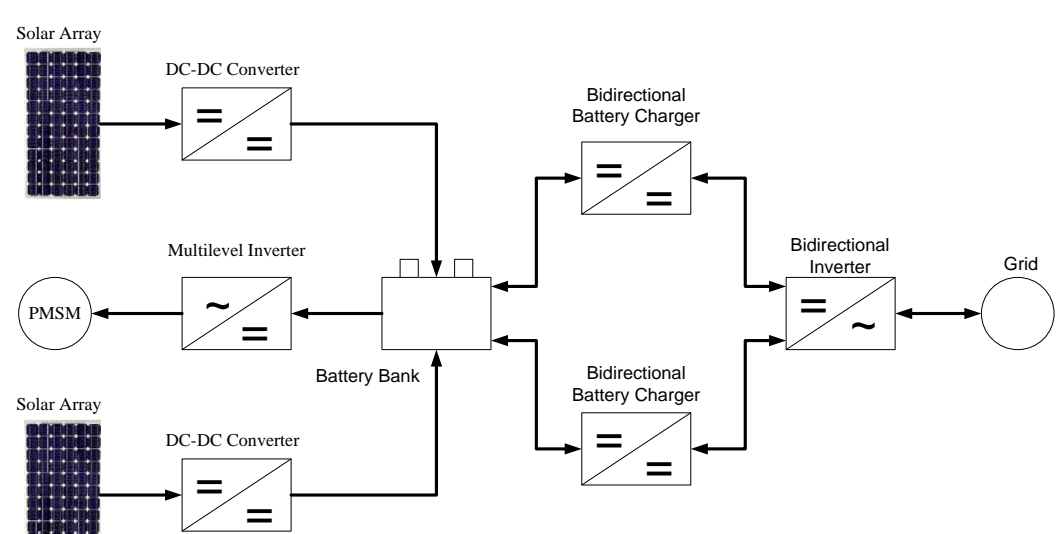

Figure 5. The solar boat system proposed in [13].

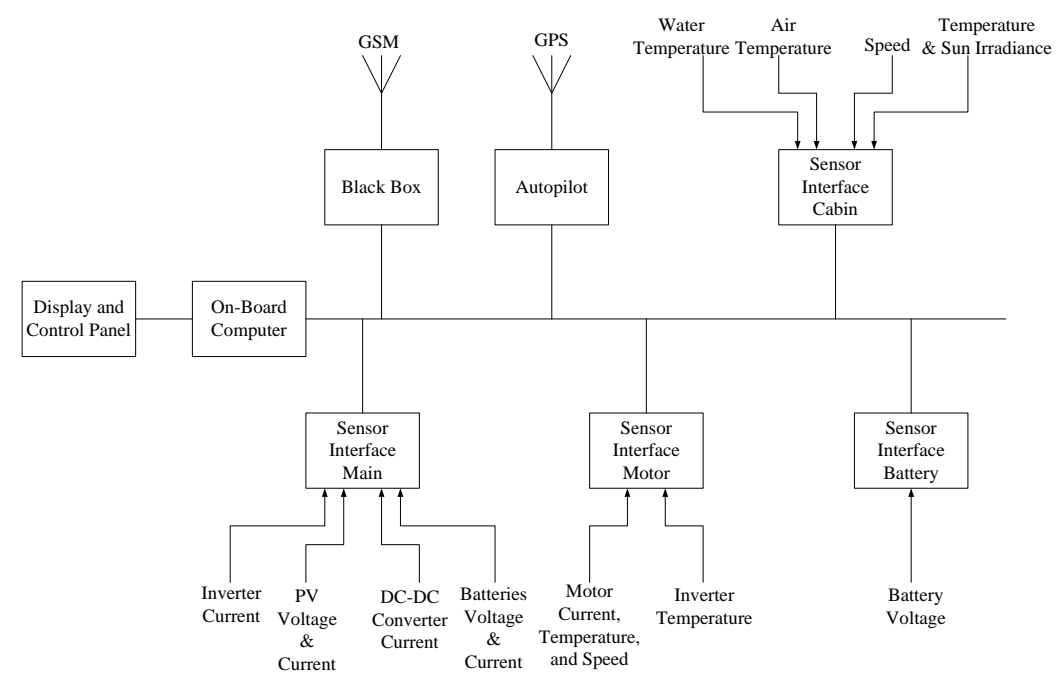

Figure 6. The diagram of Information Management System proposed in [10]. 